\title{
Regulation of the Interaction of
}

\section{Purified Human Erythrocyte AMP Deaminase and the Human Erythrocyte Membrane}

\author{
George M. Pipoly, Gene R. Nathans, Donald Chang, and Thomas F. Deuel, \\ Departments of Medicine and Biological Chemistry, Washington University \\ School of Medicine, The Jewish Hospital of St. Louis, St. Louis, Missouri \\ 63110; and Department of Biochemistry, The Pritzker School of Medicine, \\ The Franklin McLean Memorial Research Institute, The University of Chicago, \\ Chicago, Illinois 60637
}

\begin{abstract}
A B S T R A C T The binding of purified human erythrocyte AMP deaminase to human erythrocyte membranes and the effect of binding on enzyme catalytic activity was investigated. A.MP deaminase binds preferentially and specifically to the cytoplasmic surface of the erythrocyte membrane. The binding is saturable, reversible, and responsive to alterations of $\mathrm{pH}$, of ionic strength, and of ATP and AMP concentrations. A limited number $\left(\cong 2.2 \times 10^{4}\right.$ per erythrocyte) of apparently homogeneous high affinity ( $\boldsymbol{K}_{\mathrm{a}}$ $\cong 2.6 \times 10^{7} \mathrm{M}^{-1}$ ) binding sites is present. The stability of purified and endogenously bound AMP deaminase is markedly improved by the interaction with the membrane, whereas the catalytic activity of AMP deaminase is sharply reduced.

AMP deaminase displaces membrane bound glyceraldehyde 3-phosphate dehydrogenase in roughly a dose-response manner. No evidence for binding of AMP deaminase to spectrin or band 3 (the G3PD binding protein) was found in sucrose gradients, however. The interaction of AMP deaminase with the erythrocyte membrane may play an important role in the regulation of cellular adenine nucleotide metabolism.
\end{abstract}

\section{INTRODUCTION}

A number of enzymes have been found to be associated with the hemoglobin free plasma membrane of the human erythrocyte (1). Some, such as $\mathrm{Na}^{+}-\mathrm{K}^{+}$ ATPase, require disruption of the membrane by ionic detergents or high concentrations of chaotropic agents

Dr. T. Deuel holds Faculty Research Award 133 from the American Cancer Society.

Received for publication 18 October 1978 and in revised form 9 January 1.979. for solubilization and have been termed "intrinsic" membrane proteins (See Juliano [2] for review). Others, such as the glycolytic enzymes, are more easily eluted from the membrane and are readily solubilized in aqueous solutions. Of the glycolytic enzymes, the interactions of the erythrocyte membrane with glyceraldehyde-3-phosphate dehydrogenase (3-5) and aldolase (6) have been most thoroughly studied. These investigations have suggested that the interaction of the membrane with enzyme influences the regulation of the enzymes' catalytic activities (5).

Erythrocyte AMP deaminase activity was found by Rao et al. (7) to be associated with erythrocyte membranes prepared by hypotonic lysis, but not with the external surface of intact erythrocytes. Deuel et al. (8) later characterized the interaction of partially purified AMP deaminase and purified membrane fractions. In this report the characteristics of the interaction of highly purified human erythrocyte AMP deaminase and human erythrocyte membranes are described.

\section{METHODS}

AMP, ATP, and other purine and pyrimidine nucleotides were purchased from P-L Biochemicals (Milwaukee, Wis.). Acetylthiocholine and glyceraldehyde-3-phosphate were purchased from Sigma Chemical Co. (St. Louis, Mo.). Inorganic chemicals were obtained from Fisher Scientific Co. (Fair Lawn, N. J.). Human erythrocytes were obtained as outdated banked blood from the American Red Cross or were freshly drawn from volunteer donors. Dextran T110 was obtained from Pharmacia Inc., (Piscataway, N. J.). Sodium dodecyl sulfate $(\text { SDS })^{1}$ was obtained from Schwartz Mann Div.,

\footnotetext{
'Abbreviations used in this paper: DATD, N,N' dialyltartardiamide; G3PD, glyceraldehyde-3-phosphate dehydrogenase; PBS, phosphate-buffered saline; SDS, sodium dodecyl sulfate.
} 
Becton, Dickinson \& Co. (Orangeburg, N. Y.). Acrylamide and $N, N^{\prime}$ dialyltartardiamide (DATD) were purchased from BioRad Laboratories (Richmond, Calif.).

Assay of enzymatic activities. AMP deaminase activity was determined by the method of Nathans et al. (9) as adapted from Chaney and Marbach (10), and has been described in detail previously. ${ }^{2}$ Standard assays were performed when enzyme was added to $400-\mu l$ aliquots containing $2 \mathrm{mM}$ AMP, $2 \mathrm{mM}$ ATP, $100 \mathrm{mM} \mathrm{KCl}$, and $40 \mathrm{mM}$ imidazole $\mathrm{HCl}$ ( $\mathrm{pH}$ 7.32) (assay solution). The concentrations of $\mathrm{NH}_{4}{ }^{+}$produced were measured spectrophotometrically and compared to a standard curve obtained with $\mathrm{NH}_{4} \mathrm{Cl}$. At low concentrations of AMP $(0.1 \mathrm{mM})$ and in the absence of other nucleotides, AMP deaminase activity was determined by the method of Kalckar (11) as described previously. ${ }^{2}$

Acetylcholinesterase activity was determined by the method of Ellman et al. (12) as modified by Steck and Kant (13). $10 \mu \mathrm{g}$ of erythrocyte membrane protein (3 $\mu \mathrm{l}$ of concentrated erythrocyte ghosts) was diluted into $200 \mu \mathrm{l}$ of 5 $\mathrm{mM}$ sodium phosphate $\mathrm{pH} 8.0\left(5 \mathrm{P}_{8}\right)$ or $5 \mathrm{mM}$ sodium phosphate, $0.1 \%$ Triton X-100 (Rohm and Haas Co., Philadelphia, Pa.) pH 8.0 (Triton $5 \mathrm{P}_{8}$ ) and incubated for $5 \mathrm{~min}$. $500 \mu \mathrm{l}$ of $100 \mathrm{mM}$ sodium phosphate $(\mathrm{pH} 7.5), 50 \mu \mathrm{l}$ of 10 $\mathrm{mM}$ dithionitrobenzene and $50 \mu \mathrm{l}$ of $12.5 \mathrm{mM}$ acetylthiocholine were added. Enzyme activity was determined as the rate of change of $O D$ at $412 \mathrm{~nm}$. The reaction rate was linear for the first $5 \mathrm{~min}$ of assay. Activity in the presence of Triton X-100 is termed total activity, and the activity in $5 \mathrm{P}_{8}$ the exposed activity.

Glyceraldehyde-3-phosphate dehydrogenase (G3PD) activity was determined by the method of Cori et al. (14) as modified by Steck and Kant (13). $10 \mu \mathrm{g}$ of membrane protein was diluted into $200 \mu \mathrm{l}$ of $5 \mathrm{P}_{8}$ or Triton- $5 \mathrm{P}_{8}$ and incubated at $24^{\circ} \mathrm{C}$ for $5 \mathrm{~min} .620 \mu \mathrm{l}$ of $30 \mathrm{mM}$ sodium pyrophosphate ( $\mathrm{pH} 8.4$ ) made $4 \mathrm{mM}$ in cysteine- $\mathrm{HCl}$ immediately before use, $30 \mu \mathrm{l}$ of $0.4 \mathrm{M}$ sodium arsenate, 50 $\mu \mathrm{l}$ of $20 \mathrm{mM}$ nicotinamide adenine dinucleotide, and 100 $\mu l$ of $15 \mathrm{mM}$ glyceraldehyde-3-phosphate were added. The reaction was followed by monitoring the change in OD at $340 \mathrm{~nm}$. The reaction was not linear with time, and the change in OD in the 2 nd min of assay was defined as the activity.

Protein concentration. Protein concentration was determined by the method of Lowry et al. (15).

Preparation of unsealed erythrocyte ghosts. ${ }^{3}$ The methods of Steck and Kant (13) were used throughout. Erythrocytes were separated from plasma by centrifugation in a Sorvall SS-34 rotor (DuPont Instruments-Sorvall, DuPont Co., Newtown, Conn.) at 5,000 rpm $(3,000 \mathrm{~g})$ for $10 \mathrm{~min}$ and the plasma and buffy coat discarded. The erythrocytes were washed thrice in cold $0.15 \mathrm{M} \mathrm{NaCl}, 5 \mathrm{mM}$ sodium phosphate, pH 8 (PBS, phosphate-buffered saline), and lysed by the rapid addition of $40 \mathrm{vol}$ of cold $5 \mathrm{P}_{8}$. The unsealed ghosts were pelleted by centrifugation in a Sorvall GSA rotor (DuPont

${ }^{2}$ Pipoly, G. M., G. R. Nathans, D. Chang, and T. F. Deuel. Human erythrocyte AMP deaminase:activation by substrate and kinetic properties. Submitted for publication.

${ }^{3}$ The nomenclature of Steck and Kant (13) has been used to describe the permeability characteristics of membrane preparations used. Unsealed ghosts are permeable to substrates for enzymes located on the cytoplasmic surface (glyceraldehyde-3-phosphate dehydrogenase) and external surface (acetylcholinesterase) of the membrane. Sealed ghosts are permeable to substrates of external surface enzymes only and sealed inside-out vesicles are permeable to substrates for cytoplasmic surface enzymes only.
Instruments-Sorvall, DuPont Co. $)$ at $15,000 \mathrm{rpm}(27,000 \mathrm{~g})$ for $15 \mathrm{~min}$ and the supernatant solution discarded. Unsealed ghosts were repeatedly washed until all hemoglobin was removed, leaving a pearl white pellet. If AMP deaminase activity was detected in unsealed ghosts on assay, they were repeatedly washed in $5 \mathrm{P}_{8}$ until enzyme activity was not detectable. Pelleted unsealed ghosts were stored at $4^{\circ} \mathrm{C}$ and used within $10 \mathrm{~d}$

Preparation of sealed ghosts. Erythrocytes were washed and lysed in $5 \mathrm{P}_{8}$ as in preparation of unsealed ghosts. After being freed from hemoglobin and AMP deaminase, the ghosts were suspended in $40 \mathrm{vol}$ of $\mathrm{PBS}$ at $37^{\circ} \mathrm{C}$ for 40 min. They were then pelleted and washed twice in cold PBS, and stored at $4^{\circ} \mathrm{C}$ for up to $10 \mathrm{~d}$.

Preparation of sealed inside-out vesicles. Erythrocytes were washed in PBS and lysed in $40 \mathrm{vol}$ of $0.5 \mathrm{mM}$ sodium phosphate $(\mathrm{pH} 8.0)\left(0.5 \mathrm{P}_{8}\right)$ and incubated for $1 \mathrm{~h}$ at $0^{\circ} \mathrm{C}$. Membranes were then pelleted and washed in $0.5 \mathrm{P}_{8}$ until hemoglobin free. Hemoglobin free membranes were suspended in an equal volume of $0.5 \mathrm{P}_{8}$ and vesiculated by 5 passages through a No. 27 gauge hypodermic needle. Vesiculated membranes were diluted fourfold, layered on an equal volume of dextran solution $(1.10 \mathrm{~g} / \mathrm{ml})$ and centrifuged at $40,000 \mathrm{rpm}(114,000 \mathrm{~g})$ in a Sorvall (DuPont InstrumentsSorvall, DuPont Co.) OTD-65 ultracentrifuge for $2 \mathrm{~h}$ at $4^{\circ} \mathrm{C}$, using an AH 650 rotor (DuPont Instruments-Sorvall, DuPont Co.). The suspension of inside-out vesicles on top of the dextran solution was harvested, washed twice in $0.5 \mathrm{P}_{8}$, and stored at $4^{\circ} \mathrm{C}$ until use. AMP deaminase activity was not detectable in this preparation.

Purification of AMP deaminase. Human erythrocyte AMP deaminase was purified as previously described, ${ }^{4}$ employing freeze-thaw hemolysis of outdated banked erythrocytes, DEAE-cellulose chromatography, ammonium sulfate precipitation, and phosphocellulose column chromatography. The stability of the purified enzyme preparation was enhanced by including $0.5 \mathrm{mg} / \mathrm{ml}$ bovine serum albumin in all buffers. Albumin did not affect the kinetic or binding properties of the enzyme (data not shown).

Performance of binding assays. Erythrocyte membrane preparations were incubated with purified AMP deaminase under the conditions indicated in the text. Membrane suspensions were then centrifuged at $15,000 \mathrm{rpm}(12,800 \mathrm{~g})$ in an Eppendorf 5412 centrifuge (Brinkmann Instruments, Inc., Westbury, N. Y.) at $4^{\circ} \mathrm{C}$ for $10 \mathrm{~min}$, and the supernatant enzyme solution assayed for AMP deaminase activity. The pelleted membrane preparations were then washed thrice in $200-400 \mathrm{vol}$ of $10 \mathrm{mM} \mathrm{KCl}, 10 \mathrm{mM}$ imidazole $\mathrm{HCl}$ (pH 7.5). $99 \%$ of unbound AMP deaminase was removed by the second wash and no detectable enzyme activity was present in the supernate after the third wash.

Assay of pellet-bound enzyme was initiated by the addition of $400 \mu \mathrm{l}$ of assay solution to washed pelleted membranes. The pellet was suspended by vortex mixing, and the suspensions incubated at $37^{\circ} \mathrm{C}$, as in the standard assay. In experiments in which elution of bound enzyme from unsealed erythrocyte ghosts was tested, $400 \mu$ l of the test solution was added to the pelleted washed unsealed ghostenzyme complex and vortex mixed. After incubation of the suspension at $0^{\circ} \mathrm{C}$ for $15 \mathrm{~min}$, the ghosts were separated by centrifugation as above and an aliquot of the supernatant solution assayed for AMP deaminase activity. Supernatant

${ }^{4}$ Pipoly, G. M., G. R. Nathans, D. Chang, and T. F. Deuel. Human erythrocyte AMP deaminase:proteolysis to a catalytically active product during purification. Submitted for publication. 
solutions were then discarded and the pellet assayed as above. Membrane bound enzyme activity was determined directly by the addition of the assay solution to pelleted erythrocyte membranes. The supernatant materials were assayed to assure that inactivation of the enzyme had not occurred. In all experiments at least $80 \%$, and usually $>90 \%$, of eluted enzymatic activity was recovered in the supernatant solution.

Extraction of glyceraldehyde-3-phosphate dehydrogenase from unsealed erythrocyte ghosts. Hemoglobin free unsealed erythrocyte ghosts prepared by hypotonic lysis in $5 \mathrm{P}_{8}$ were incubated in $20 \mathrm{vol}$ of $55 \mathrm{mM}$ sodium phosphate (pH 8.0) for $20 \mathrm{~min}$ at $0^{\circ} \mathrm{C}$, as described by Kant and Steck (5). After separation of the membranes by centrifugation, the supernatant solution was dialyzed against 1,000 vol of 10 $\mathrm{mM} \mathrm{KCl}, 10 \mathrm{mM}$ imidazole $\mathrm{HCl}(\mathrm{pH} 7.5)$, or $5 \mathrm{P}_{8}$ and concentrated by pressure dialysis across an Amicon PM-10 membrane using the Amicon ultrafiltration system (Amicon Corp., Scientific Sys. Div., Lexington, Mass.).

SDS-polyacrylamide gel electrophoresis. SDS gel electrophoresis was performed by an adaptation of the method of Fairbanks et al. (16) as previously described ${ }^{4}$ utilizing $0.2 \%$ SDS, $7.5 \%$ acrylamide (7.3:1 acrylamide:DATD) in Tris acetate ( $\mathrm{pH} 7.4)$

Preparation of erythrocyte membrane fractions. ${ }^{5}$ Spectrin (bands 1 and 2) and actin (band 5) were solubilized from unsealed erythrocyte ghosts by incubation of washed hemoglobin free ghosts in $2 \mathrm{vol}$ of $1 \mathrm{mM}$ EDTA ( $\mathrm{pH} 8.0$ ) and dialysis against $1,000 \mathrm{vol}$ of the diluent at $4^{\circ} \mathrm{C}$, as described by Lux et al. (18).

After removal of the membrane pellet by centrifugation, the EDTA supernate was dialyzed against $5 \mathrm{P}_{8}$ or $10 \mathrm{mM} \mathrm{KCl}$, $10 \mathrm{mM}$ imidazole $(\mathrm{pH} 7.5)$ and concentrated by vacuum dialysis. SDS gel electrophoresis of this material showed essentially a pure preparation of bands 1 and 2 with minor contamination by band 5 .

Band 3 was solubilized from hemoglobin-free, glyceraldehyde-3-phosphate depleted unsealed ghosts by incubation in 5 vol of $0.5 \%$ Triton $\mathrm{X}-100$ in $35 \mathrm{mM}$ sodium phosphate (pH 8.0) at $0^{\circ} \mathrm{C}$ for $20 \mathrm{~min}$ as described by $\mathrm{Yu}$ and Steck (19). The Triton wash was dialyzed against $10 \mathrm{mM} \mathrm{KCl}, 10 \mathrm{mM}$ imidazole $\mathrm{HCl}(\mathrm{pH} 7.5), 5 \mathrm{P}_{8}$, or Triton $5 \mathrm{P}_{8}$, and concentrated by pressure dialysis across an Amicon PM-10 membrane using the Amicon ultrafiltration system. SDS gel electrophoresis of this material showed predominantly band 3 with minor contamination by bands 1 and 2 .

Sucrose gradient ultracentrifugation. Samples of $0.5 \mathrm{ml}$ were applied to $4 \mathrm{ml}$ continuous $5-20 \%$ sucrose gradients in $30 \mathrm{mM} \mathrm{KCl}, 10 \mathrm{mM}$ imidazole $\mathrm{HCl}(\mathrm{pH} \mathrm{7.5)}$ with and without $0.5 \%$ Triton $\mathrm{X}-100,5 \mathrm{P}_{8}$, or $0.5 \%$ Triton- $5 \mathrm{P}_{8}$ in Beckman cellulose nitrate centrifugation tubes (Beckman Instruments, Inc., Spinco Div., Palo Alto, Calif.). Centrifugation was performed in a Sorvall OTD 65 ultracentrifuge using an AH 650 rotor, at $35,000 \mathrm{rpm}(150,000 \mathrm{~g})$ for $10 \mathrm{~h}$ at $4^{\circ} \mathrm{C}$, using hemoglobin as a marker. Approximately $0.2-\mathrm{ml}$ fractions were collected utilizing the ISCO fraction collector system (Instrumentation Specialties Co., Lincoln, Nebr.).

\section{RESULTS}

Characteristics of the membrane preparations used are summarized in Table I. With unsealed ghosts, acetyl-

${ }^{5}$ The system proposed by Fairbanks et al. (16) and modified by Steck (17) has been adopted for identification of polypeptide bands on SDS gels of erythrocyte membranes.
TABLE I

Characteristics of Erythrocyte Ghosts

\begin{tabular}{|c|c|c|c|c|c|}
\hline \multirow[b]{2}{*}{ Preparation } & \multirow{2}{*}{$\begin{array}{l}\text { Protein } \\
\text { concen- } \\
\text { tration }\end{array}$} & \multicolumn{2}{|c|}{$\begin{array}{c}\text { Cholinesterase } \\
\text { activity }\end{array}$} & \multicolumn{2}{|c|}{$\begin{array}{l}\text { Glyceraldehyde-3- } \\
\text { phosphate dehydro- } \\
\text { genase activity }\end{array}$} \\
\hline & & Total ${ }^{*}$ & Exposed $\ddagger$ & Total* & Exposedt \\
\hline & $m g / m l$ & \multicolumn{2}{|c|}{$\triangle O D^{+12} \min$} & \multicolumn{2}{|c|}{$\triangle O D^{3+0} \mathrm{~min}$} \\
\hline $\begin{array}{c}\text { Inside-out } \\
\text { vesicles }\end{array}$ & 3.4 & 0.138 & 0.025 & 0.102 & 0.084 \\
\hline $\begin{array}{l}\text { Sealed } \\
\text { ghosts }\end{array}$ & $5 .()$ & 0.243 & 0.238 & 0.013 & 0.009 \\
\hline $\begin{array}{l}\text { Unsealed } \\
\text { ghosts }\end{array}$ & 5.4 & (0.190 & 0.198 & 0.086 & 0.106 \\
\hline
\end{tabular}

* Total activity: enzymatic activity in the presence of Triton $5 \mathrm{P}_{8}$.

$\$$ Activity exposed: enzymatic activity in $5 \mathrm{P}_{8}$.

cholinesterase activity, a marker for the external erythrocyte membranes and glyceraldehyde-3-phosphate dehydrogenase activity, a marker for the inner membrane surface, are equally accessible in the presence and absence of Triton X-100. Assay of the sealed inside-out vesicles suggests $\cong 20 \%$ contamination with unsealed ghosts or sealed ghosts. Assay of sealed ghosts demonstrates complete accessibility of acetylcholinesterase. The low activity for glyceraldehyde3-phosphate dehydrogenase activity in sealed ghosts is attributable to elution of the enzyme during sealing in $150 \mathrm{mM} \mathrm{NaCl}$.

Saturability of erythrocyte membrane binding and specificity of binding. In these experiments increasing concentrations of purified AMP deaminase were incubated at $0^{\circ} \mathrm{C}$ with unsealed erythrocyte ghosts. After separation by centrifugation, supernatant buffer and pelleted membranes were assayed for AMP deaminase activity. Fig. 1 shows the resultant plot of enzyme activity bound versus enzyme concentration in the reaction mixture. Scatchard (20) analysis of the data (inset) revealed $K_{\mathrm{a}} \cong 2.6 \times 10^{7} \mathrm{M}^{-1}$ and $\cong 2.2 \times 10^{4}$ binding sites per erythrocyte ghost, assuming that there were $6 \times 10^{9}$ ghosts/ $\mu$ l (5). From the known molecular weight and specific activity of purified AMP deaminase $e^{4}$ and the AMP deaminase activity present in erythrocyte lysates, there were calculated to be $3 \times 10^{3}$ AMP deaminase molecules per erythrocyte. Hence, binding sites are present in $\cong 10$-fold excess over the number of intracellular enzyme molecules (data not shown).

Fig. 2 presents the results of experiments in which increasing concentrations of AMP deaminase were incubated with sealed inside-out vesicles or sealed ghosts after which pelleted membranes were assayed for bound AMP deaminase activity. At all enzyme concentrations there was approximately sevenfold greater binding to the internal (inside-out vesicles) 


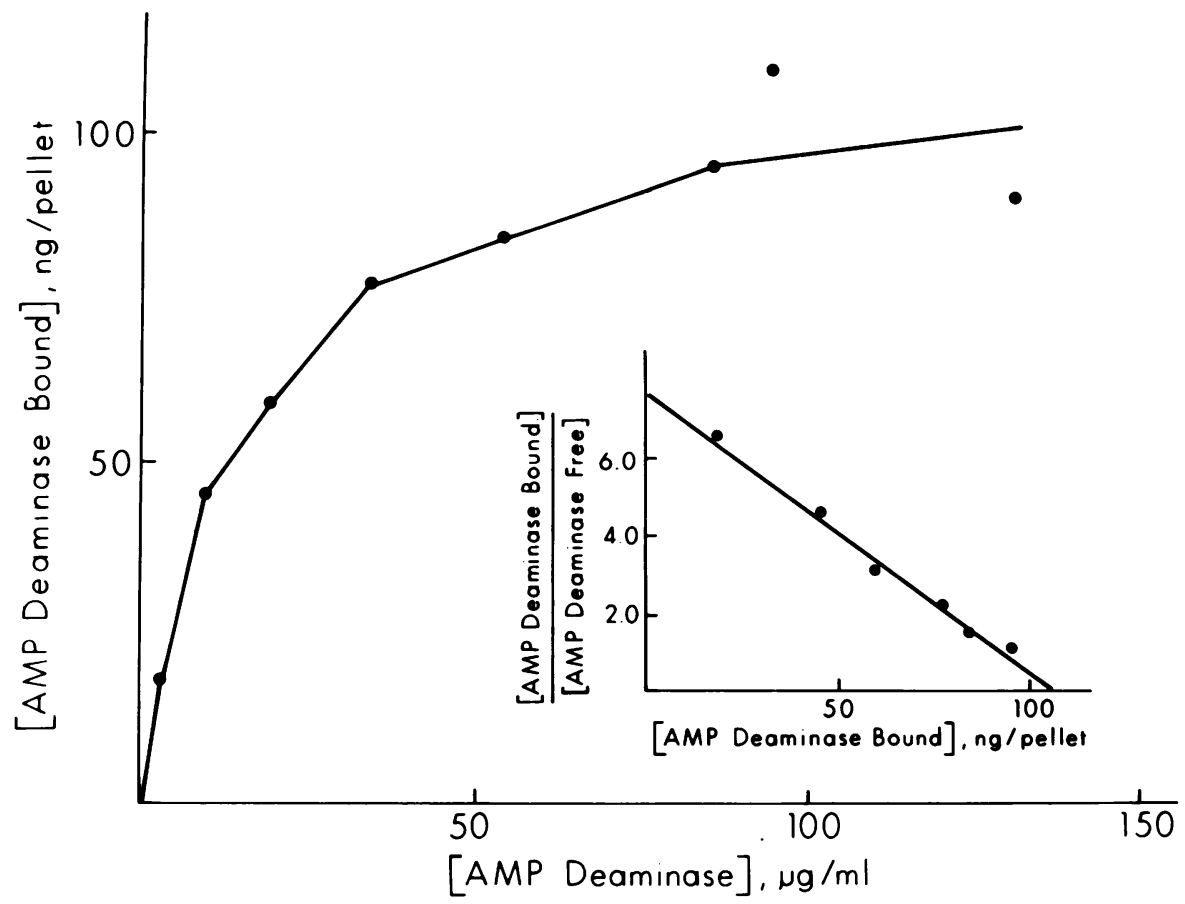

FIGURE 1 Binding of purified AMP deaminase to unsealed erythrocyte ghosts. Unsealed erythrocyte ghosts ( $7.2 \mu \mathrm{g}$ membrane protein) were incubated with increasing concentrations of purified AMP deaminase as shown, in $200 \mu \mathrm{l}$ of $45 \mathrm{mM} \mathrm{KCl}, 5 \mathrm{mM}$ potassium phosphate, $0.5 \mathrm{mg} / \mathrm{ml}$ albumin $\mathrm{pH} 7.5$ at $0^{\circ} \mathrm{C}$ for $15 \mathrm{~min}$. The suspension was centrifuged at $12,800 \mathrm{~g}$ for $15 \mathrm{~min}$ and free enzyme activity in the supernatant solution determined. The pellet was then washed twice in $400 \mu \mathrm{l}$ of 10 $\mathrm{mM} \mathrm{KCl}, 10 \mathrm{mM}$ imidazole $\mathrm{HCl} \mathrm{pH} 7.5$ and assayed for bound AMP deaminase activity. Analysis of the Scatchard plot of the data (inset) revealed $K_{\mathrm{a}} \cong 2.6 \times 10^{7} \mathrm{M}^{-1}$ and $n \cong 2.2 \times 10^{4}$ binding sites per ghost. In the Scatchard analysis of the data, enzyme bound is expressed in $\mathrm{ng} /$ pellet. The data were derived from the known specific activity of AMP deaminase in the incubation mixture (210 $\mu \mathrm{mol} \mathrm{NH}_{4}$ released/mg per $\mathrm{min}$ ).

than external (sealed ghosts) membrane surface. The data have been corrected for contamination of the ghost preparations. The data illustrated were taken from the lower end of the binding curve where the enzyme bound is a nearly linear function of enzyme added. Additional enzyme added to insideout vesicles, but not sealed ghosts, results in saturation of the available sites similar to that seen in Fig. 1 (data not shown).

Kinetics of binding and release. In the experiments represented in Fig. 3, AMP deaminase was incubated with unsealed erythrocyte ghosts at $0^{\circ} \mathrm{C}$ for increasing intervals before centrifugation and assayed for bound enzyme activity. Equilibrium was rapid; binding was maximal at $15 \mathrm{~min}$ and binding was unchanged from $15 \mathrm{~min}$ to $1 \mathrm{~h}$. The binding at 0 time reflects the binding resulting from the mixing of enzyme with unsealed ghosts immediately before centrifugation, hence binding which occurred during separation of free enzyme from membrane. In similar experiments in which bound AMP deaminase was eluted from unsealed erythrocyte ghosts with $\mathrm{KCl}$ or ATP, the enzyme activity remaining bound after
15 min incubation was unchanged after 30 and 45 min incubation.

Effect of $\mathrm{KCl}$ and $p H$ on the release of $A M P$ deaminase from unsealed erythrocyte ghosts. In the experiments represented in Fig. 4, AMP deaminase was incubated with unsealed erythrocyte ghosts and the pellet washed free of unbound enzyme activity. Ghosts were then suspended in buffers of increasing $\mathrm{KCl}$ concentrations or $\mathrm{pH}$ as shown in the legend for 15 min, separated by centrifugation, and supernatant solution and pellet assayed for enzyme activity. $\mathrm{KCl}$ had no effect on AMP deaminase release below $50 \mathrm{mM}$, but there was progressive increase in enzyme release between 50 and $200 \mathrm{mM}$ with $50 \%$ release at $\cong 100$ $\mathrm{mM} \mathrm{KCl}$. Similar results were obtained when $\mathrm{CsCl}$ and $\mathrm{NaCl}$ were substituted for $\mathrm{KCl}$. There was little enzyme released at $50 \mathrm{mM} \mathrm{KCl}$ with $\mathrm{pH}$ range of 6.0 to 7.5 , but $\cong 80 \%$ of bound enzyme was released when the $\mathrm{pH}$ was increased from 7.5 to 8.5 .

Effect of nucleotides on AMP deaminase binding to open erythrocyte ghosts. A number of purine and pyrimidine nucleotides were tested for their ability to promote the dissociation of AMP deaminase from 


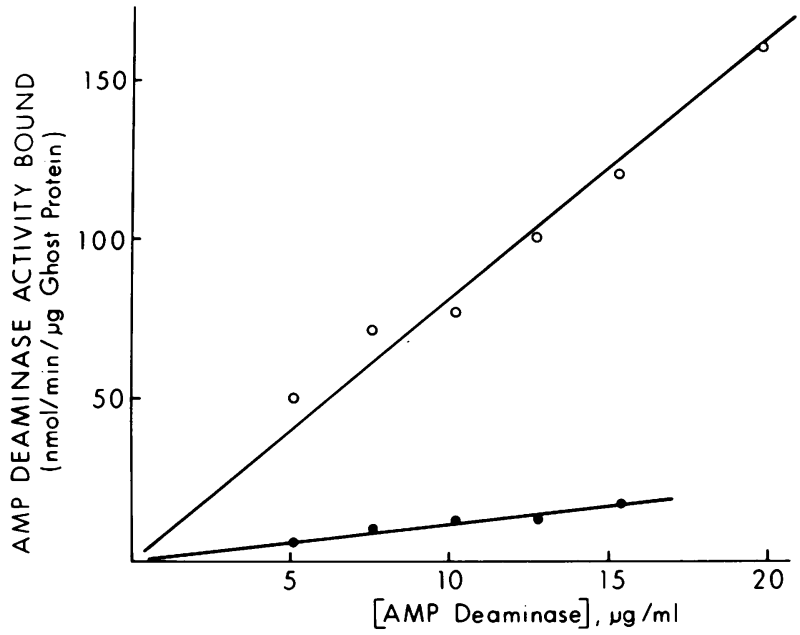

FIgURE 2 Specificity of binding of AMP deaminase to the surface of erythrocyte membranes. Sealed inside-out vesicles (85 $\mu \mathrm{g}$ membrane protein $/ \mathrm{ml}, 0$ ) or sealed ghosts (122.5 $\mu \mathrm{g}$ membrane protein $/ \mathrm{ml}, \bigcirc)$ were incubated with increasing concentrations of AMP deaminase, pelleted, and washed as described for Fig. 1. The pellets were then assayed for bound AMP deaminase activity. Within experimental limits, the binding function obtained with inside-out vesicles was identical to that shown in Fig. 1 .

unsealed erythrocyte ghosts. The results, summarized in Table II, show that triphosphate nucleotides, AMP, and inorganic phosphate effectively dissociated the enzyme membrane complex. Isomers of AMP, adenosine, and adenine were relatively ineffective in promoting dissociation. Membrane bound enzyme exposed to AMP resulted in substantial release of AMP deaminase. During the incubation period required

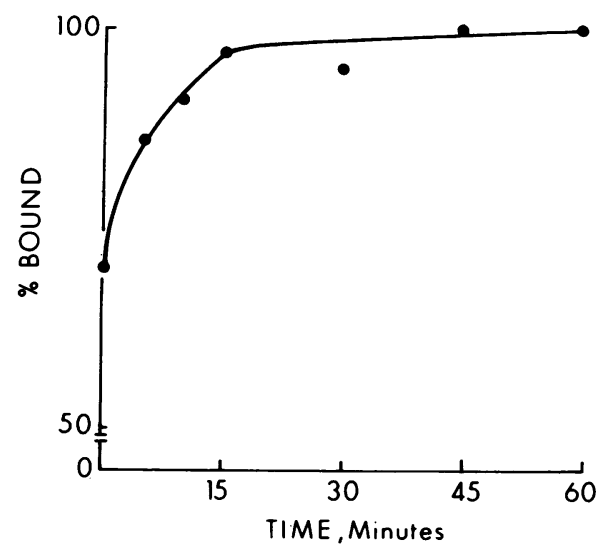

FIgURE 3 Kinetics of binding of AMP deaminase to unsealed erythrocyte ghosts. Unsealed erythrocyte ghosts $(2.0 \mathrm{mg}$ membrane protein $/ \mathrm{ml}$ ) were incubated with purified AMP deaminase $(20.5 \mu \mathrm{g} / \mathrm{ml})$ at $0^{\circ} \mathrm{C}$ for variable times as shown. At time 0 , the suspensions were centrifuged and the pellets were washed as described for Fig. 1. Pellets were then assayed for AMP deaminase activity.
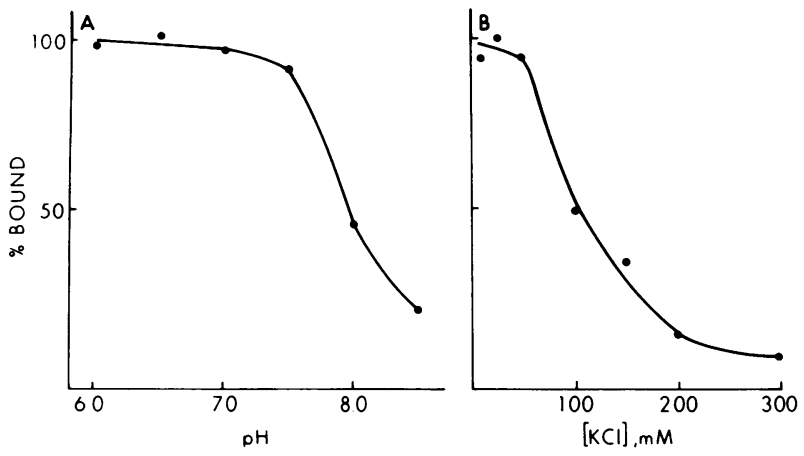

FigURE 4 (A) Effect of $\mathrm{pH}$ on release of AMP deaminase from unsealed erythrocyte ghosts. Unsealed erythrocyte ghosts (39.6 $\mu \mathrm{g}$ membrane protein $/ \mathrm{ml}$ ) were incubated with AMP deaminase $(5.1 \mu \mathrm{g} / \mathrm{ml})$, pelleted, and washed as described in the legend to Fig. 1. The washed pellets were suspended in $400 \mu \mathrm{l}$ of $50 \mathrm{mM} \mathrm{KCl}, 10 \mathrm{mM}$ imidazole $\mathrm{HCl}, 0.5 \mathrm{mg} / \mathrm{ml}$ albumin at variable $\mathrm{pH}$ as shown, and incubated at $0^{\circ} \mathrm{C}$ for $30 \mathrm{~min}$. Ghosts were then pelleted and enzyme activity bound to the pellet determined. (B) Effect of $\mathrm{KCl}$ on release of AMP deaminase from unsealed erythrocyte ghosts. Unsealed erythrocyte ghosts (19.8 $\mu \mathrm{g}$ membrane protein $/ \mathrm{ml}$ ) were incubated with AMP deaminase $(5.1 \mu \mathrm{g} / \mathrm{ml})$, pelleted, and washed as described in the legend to Fig. 1. The washed pellets were suspended in $400 \mu \mathrm{l}$ of variable $\mathrm{KCl}, 10 \mathrm{mM}$ imidazole $\mathrm{HCl}, 0.5 \mathrm{mg} / \mathrm{ml}$ albumin $\mathrm{pH} 7.5$, and incubated at $0^{\circ} \mathrm{C}$ for $30 \mathrm{~min}$. Ghosts were then pelleted and enzyme activity bound to the pellet determined.

for release, ammonia generated by released enzyme accumulates and is measured during subsequent assay. This added product likely accounts for the excessive "recovery" of enzyme noted in the experiment using AMP to release enzyme.

The effects of AMP and ATP were examined in detail as shown in Fig. 5. In these experiments, unsealed ghost-enzyme complex was suspended in buffer with increasing concentrations of AMP, ATP, or equimolar concentrations of ATP and $\mathrm{Mg}^{++}$(ATP$\mathrm{Mg}^{++}$) for $15 \mathrm{~min}$, then separated by centrifugation, washed, and the pellet assayed for AMP deaminase activity. Increasing concentrations of AMP from 50 to $500 \mu \mathrm{M}$ resulted in a linear increase in AMP deaminase release. In contrast, ATP and ATP- $\mathrm{Mg}^{++}$ resulted in marked enzyme release at $25 \mu \mathrm{M}$ and essentially maximal enzyme release at $100 \mu \mathrm{M}$. There was no difference in the effect of ATP and ATP- $\mathrm{Mg}^{++}$. However, $\mathrm{Mg}^{++}$did antagonize ATP promoted dissociation of the enzyme-membrane complex when present in 10- to 16-fold excess both at low and high ATP concentrations (Table III). The ability of ATP to promote the release of bound AMP deaminase was dependent on pH. As shown in Table IV, a marked reduction in ATP dependent AMP deaminase release was seen when the $\mathrm{pH}$ was reduced from 7.5 to 6.5 .

Comparison of purified and dissociated AMP deaminase. Purified human erythrocyte AMP deami- 
TABLE II

Effects of Nucleotides on AMP Deaminase Release from Unsealed Erythrocyte Ghosts

\begin{tabular}{lcc}
\hline \multicolumn{1}{c}{ Compound } & $\begin{array}{c}\text { Activity recovered in } \\
\text { supernatant solution }\end{array}$ & $\begin{array}{c}\text { Activity in } \\
\text { pellet }\end{array}$ \\
\hline & \multicolumn{2}{c}{$\%$} \\
Adenine & 1 & \\
Deoxy AMP & 0 & 108 \\
Adenosine 2' monophosphate & 8 & 97 \\
cAMP & 31 & 83 \\
UMP & 12 & 78 \\
KPi & 25 & 71 \\
Adenosine 3' monophosphate & 35 & 64 \\
CTP & 67 & 62 \\
CMP & 30 & 50 \\
GMP & 63 & 44 \\
XMP & 83 & 21 \\
AMP & 75 & 19 \\
UTP & 140 & 18 \\
XTP & 78 & 15 \\
ITP & 82 & 14 \\
ATP & 105 & 13 \\
& 90 & 10 \\
\hline
\end{tabular}

Unsealed erythrocyte ghosts ( $36 \mu \mathrm{g}$ membrane protein/ml) were incubated with AMP deaminase $(8.4 \mu \mathrm{g} / \mathrm{ml})$, pelleted, and washed as described in the legend to Fig. 1. Washed pellets were suspended in $400 \mu \mathrm{l}$ of $50 \mathrm{mM} \mathrm{KCl}, 20 \mathrm{mM}$ immidazole $\mathrm{HCl}, 0.5 \mathrm{mg} / \mathrm{ml}$ albumin, and 2 or $2.5 \mathrm{mM}$ of the compounds listed and incubated for $30 \mathrm{~min}$ at $0^{\circ} \mathrm{C}$. Ghosts were then pelleted and enzymatic activity in the supernatant solution and pellet determined. Results are expressed as percentage of total activity bound to the pellet in the control experiment. All other nucleotides are 5 '-derivatives unless otherwise specifically noted.

nase has been shown to be activated by ATP and $\mathrm{KCl}$, and in the presence of these activators follows Michaelis-Menten kinetics with an apparent $K_{\mathrm{m}}$ for AMP of $1.1 \mathrm{mM}^{2}$ To assess whether enzyme was modified by membrane binding and subsequent elution, the apparent $K_{m}$ of the enzyme for AMP was compared using purified enzyme and enzyme bound to membrane and eluted from the membrane during assay. Membrane-enzyme complexes were prepared by incubating purified AMP deaminase with unsealed erythrocyte ghosts, then by washing the pelleted ghosts free of unbound enzyme activity. The initial reaction velocity for the deamination of increasing concentrations of AMP in the presence of $2 \mathrm{mM}$ ATP and $100 \mathrm{mM} \mathrm{KCl}$ by added enzyme-ghost complex was then determined. It should be noted that the conditions of assay utilized in this experiment result in dissociation of membrane-enzyme complexes (high $\mathrm{KCl}$, high ATP). The results, presented in Fig. 6, demonstrate that the released enzyme follows $\mathrm{Mi}$ chaelis-Menten kinetics with an apparent $K_{\mathrm{m}}$ of 1.1

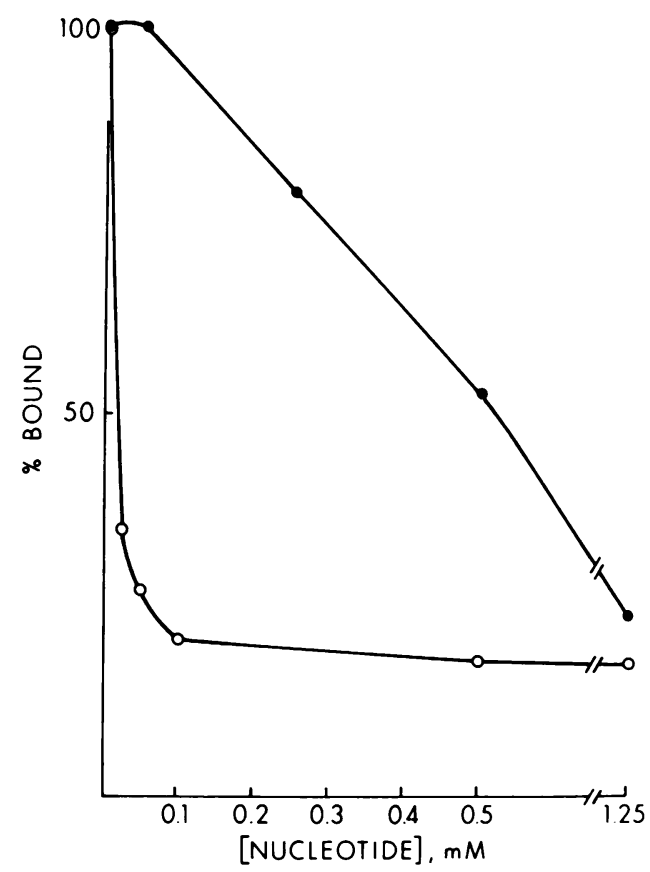

FIGURE 5 Effect of ATP, ATP-MG ${ }^{++}$, and AMP on release of AMP deaminase from unsealed erythrocyte ghosts. Unsealed erythrocyte ghosts were incubated with purified AMP deaminase, pelleted and washed as described in the legend to Fig.l. The washed pellets were suspended in $400 \mu$ l of variable concentrations of ATP, ATP- $\mathbf{M g}^{++}$complex (prepared as an equimolar solution of ATP and $\mathrm{MgCl}_{2}$ ) or AMP in $50 \mathrm{mM} \mathrm{KCl}$, $0.5 \mathrm{mg} / \mathrm{ml}$ albumin, $10 \mathrm{mM}$ imidazole $\mathrm{HCl} \mathrm{pH} \mathrm{7.5,} \mathrm{and} \mathrm{incu-}$ bated at $0^{\circ} \mathrm{C}$ for $15 \mathrm{~min}$. The ghosts were then separated and bound AMP deaminase activity determined. 9 , AMP; O, ATP. The curve for ATP- $\mathrm{Mg}^{++}$is superimposable on the ATP curve, and hence has not been represented in the figure.

TABLE III

Effect of Excess Magnesium on AMP Deaminase Release from Unsealed Erythrocyte Ghosts

\begin{tabular}{|c|c|c|}
\hline [ATP] & {$[\mathrm{Mg}]$} & AMP deaminase activity bound \\
\hline \multicolumn{2}{|c|}{$m M$} & $\%$ \\
\hline 0 & 0 & 100 \\
\hline 0 & 0.5 & 100 \\
\hline 0 & 2.0 & 100 \\
\hline 0.05 & 0 & 40 \\
\hline 0.05 & 0.05 & 44 \\
\hline 0.05 & 0.5 & 71 \\
\hline 0.5 & 0 & 20 \\
\hline 0.5 & 1 & 29 \\
\hline 0.5 & 5 & 32 \\
\hline 0.5 & 8 & 49 \\
\hline
\end{tabular}

Unsealed erythrocyte ghosts $(22.0 \mu \mathrm{g}$ ghost protein/ml) were incubated with purified AMP deaminase $(8.4 \mu \mathrm{g} / \mathrm{ml})$, pelleted, and washed as described in the legend to Fig. 1. The washed pellets were suspended in $400 \mu \mathrm{l}$ of $50 \mathrm{mM} \mathrm{KCl}$, $20 \mathrm{mM}$ imidazole $\mathrm{HCl}, 0.5 \mathrm{mg} / \mathrm{ml}$ albumin, and ATP- $\mathrm{Mg}^{++}$ as shown and incubated for $15 \mathrm{~min}$ at $0^{\circ} \mathrm{C}$. The ghosts were then pelleted and bound enzymatic activity determined. 
TABLE IV

Effect of pH on ATP-Promoted Release of AMP Deaminase from Unsealed Erythrocyte Ghosts

\begin{tabular}{lcc}
\hline ATP & $\mathrm{pH}$ & Percent bound \\
\hline$m M$ & & $\%$ \\
0 & 6.5 & 100 \\
0 & 7.5 & 83 \\
0.05 & 6.5 & 98 \\
0.05 & 7.5 & 26 \\
0.5 & 6.5 & 53 \\
0.5 & 7.5 & 22 \\
\hline
\end{tabular}

Unsealed erythrocyte ghosts (400 $\mu$ g ghost protein $/ \mathrm{ml}$ ) were incubated with purified AMP deaminase $(40 \mu \mathrm{g} / \mathrm{ml})$, pelleted, and washed as described in the legend to Fig. 1. Washed pellets were then suspended in $400 \mu \mathrm{l}$ of $50 \mathrm{mM} \mathrm{KCl}, 0.5$ $\mathrm{mg} / \mathrm{ml}$ albumin, $20 \mathrm{mM}$ imidazole $\mathrm{HCl}$, and ATP and $\mathrm{pH}$ as shown and incubated at $0^{\circ} \mathrm{C}$ for $15 \mathrm{~min}$. Ghosts were then pelleted and bound AMP deaminase activity was determined.

$\mathrm{mM}$. Therefore the process of membrane binding and release does not alter the kinetic properties of the enzyme, as implied by the identical apparent $K_{\mathrm{m}}$ of purified and released AMP deaminase.

Effect of erythrocyte membranes on stability of AMP deaminase. The intrinsic AMP deaminase ac- tivity of unsealed ghosts prepared by hypotonic lysis and washed free of hemoglobin in low ionic strength phosphate free buffer was stable $(<10 \%$ loss of catalytic activity) for more than $2 \mathrm{~h}$ at $24^{\circ} \mathrm{C}$. The effect of unsealed erythrocyte ghosts on the stability of AMP deaminase in solution was tested by incubating enzyme in buffer in the presence and absence of unsealed ghosts at $24^{\circ} \mathrm{C}$ and assaying the solution at various times for deaminase activity. The results, presented in Table $\mathrm{V}$, indicate that the stability of the enzyme is enhanced by the presence of erythrocyte membranes. It must be appreciated that purified AMP deaminase has been previously shown to be highly unstable in solution and that the stability of multiple preparations has been found to be maximally enhanced by the presence of ATP and $\mathrm{KCl}$. Albumin and 2-mercaptoethanol have variable but lesser effects on AMP deaminase stability. ${ }^{2,3}$ Hence, the data presented suggest marked enhancement of AMP deaminase stability by erythrocyte membranes.

Effect of membrane binding on the activity of AMP deaminase. In the experiment depicted in Fig. 7, AMP deaminase was incubated with unsealed erythrocyte ghosts for $15 \mathrm{~min}$ and the ghosts subsequently washed free of excess deaminase activity. Membrane enzyme complexes were then suspended and incubated under the following conditions: $(a)$ absent $\mathrm{KCl}$, to insure minimal activation by $\mathrm{K}^{+}$and

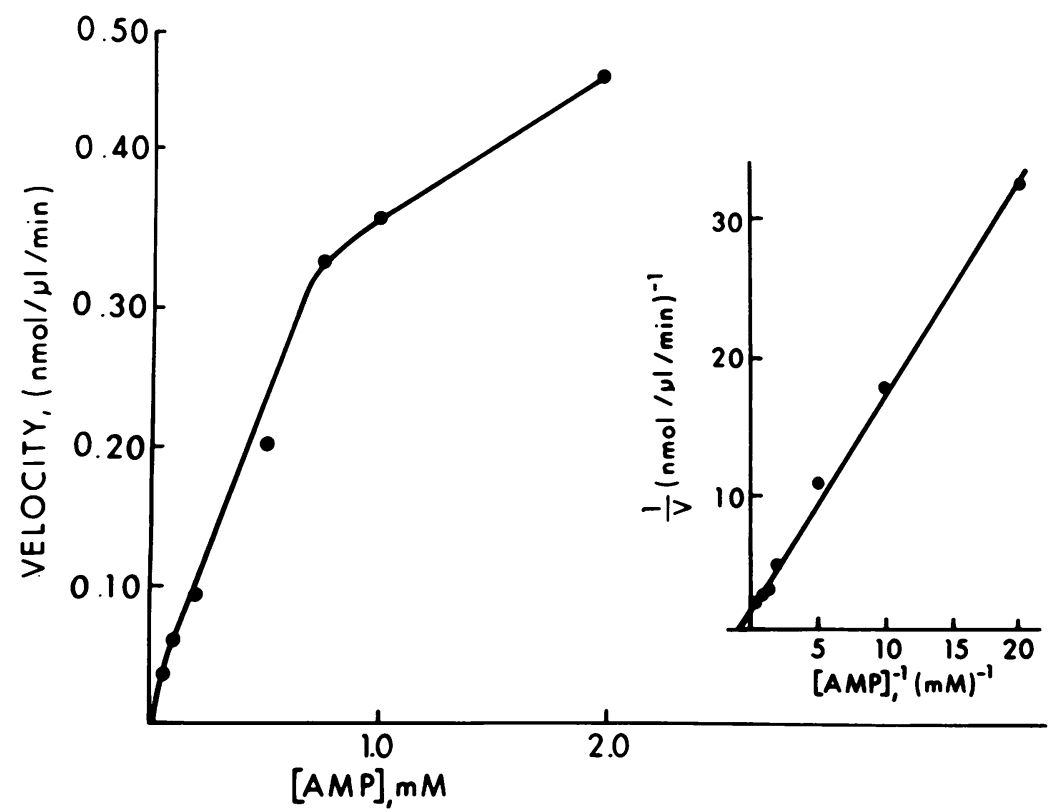

FIGURE 6 Effect of substrate concentration on initial reaction velocity for AMP deaminase bound to unsealed erythrocyte ghosts. Unsealed erythrocyte ghosts were incubated with purified AMP deaminase, pelleted, and washed as described in the legend to Fig. 1 . The washed pellets were suspended in $1,000 \mu \mathrm{l}$ of $50 \mathrm{mM} \mathrm{KCl}, 40 \mathrm{mM}$ imidazole $\mathrm{HCl}, 0.5 \mathrm{mg} / \mathrm{ml}$ albumin pH 7.5. The initial reaction velocity with varied concentrations of AMP in $100 \mathrm{mM} \mathrm{KCl}, 2 \mathrm{mM} \mathrm{ATP}$, and $40 \mathrm{mM}$ imidazole $\mathrm{HCl}$ pH 7.5 was determined. Inset: Double reciprocal plot of the data. 
TABLE V

Effect of Unsealed Erythrocyte Ghosts on the Stability of Purified AMP Deaminase

\begin{tabular}{ccc}
\hline Time of incubation & Relative activity buffer & $\begin{array}{c}\text { Relative activity buffer } \\
\text { and ghosts }\end{array}$ \\
\hline $\min$ & & $\%$ \\
0 & 100 & 100 \\
5 & & 83 \\
11 & 50 & 77 \\
15 & 33 & 72 \\
30 & 22 & 83 \\
\hline
\end{tabular}

Purified AMP deaminase was diluted to $21 \mu \mathrm{g} / \mathrm{ml}$ in $2 \mathrm{mM}$ ATP, $100 \mathrm{mM} \mathrm{KCl}, 40 \mathrm{mM}$ imidazole $\mathrm{HCl} \mathrm{pH} 7.3$ (buffer) or in $2 \mathrm{mM} \mathrm{ATP}, 100 \mathrm{mM} \mathrm{KCl}, 40 \mathrm{mM}$ imidazole $\mathrm{HCl}$, and unsealed ghosts $(2 \mathrm{mg}$ ghost protein/ml). Diluted enzyme was incubated at $24^{\circ} \mathrm{C}$ for the times indicated, then analyzed for AMP deaminase activity. Similar experiments performed with freshly prepared unsealed erythrocyte ghosts before removal of endogenous AMP deaminase showed stable enzymatic activity (100\%) after $140 \mathrm{~min}$.

minimal KCl-promoted dissociation of enzyme from the membrane, (b) $50 \mathrm{mM} \mathrm{KCl}$, to insure full activation of the enzyme but minimal KCl-promoted dissociation of enzyme from the membrane, and (c) $200 \mathrm{mM}$ $\mathrm{KCl}$, to insure full dissociation from the membrane and full activation of enzyme by $\mathrm{KCl}$. Aliquots of each suspension were then assayed under conditions such that the final $\mathrm{KCl}$ concentration in assay was $<5 \mathrm{mM}$ or $50-55 \mathrm{mM}$. Assays were performed at $0.1 \mathrm{mM}$ AMP and without ATP so that nucleotide-promoted dissociation of enzyme membrane complexes could be avoided. As can be seen from Fig. 7, at low and high $\mathrm{KCl}$ in assay, a marked increase in catalytic activity is seen after incubation of membrane-enzyme complexes in $200 \mathrm{mM} \mathrm{KCl}$. In control experiments, the above preincubation conditions did not affect AMP deaminase activity when assayed under dissociating conditions ( $2 \mathrm{mM}$ AMP, $2 \mathrm{mM}$ ATP). The reduced catalytic activity of membrane bound enzyme can be explained in two possible ways: $(a)$ all enzyme is bound and has a low level of activity; $(b)$ a small amount of enzyme, free from membranes, is fully active and the membrane bound enzyme has no activity at all. These experiments do not distinguish between these possibilities. Whichever interpretation is correct, membraneassociated enzyme, not eluted by $\mathrm{KCl}$ during preincubation, has substantially lowered intrinsic specific activity or, alternatively, does not provide access to the enzyme for substrate by virtue of steric hindrance related to the membrane-enzyme complex.

Effect of AMP deaminase binding on the binding of glyceraldehyde-3-phosphate dehydrogenase to erythrocyte ghosts. Unsealed erythrocyte ghosts

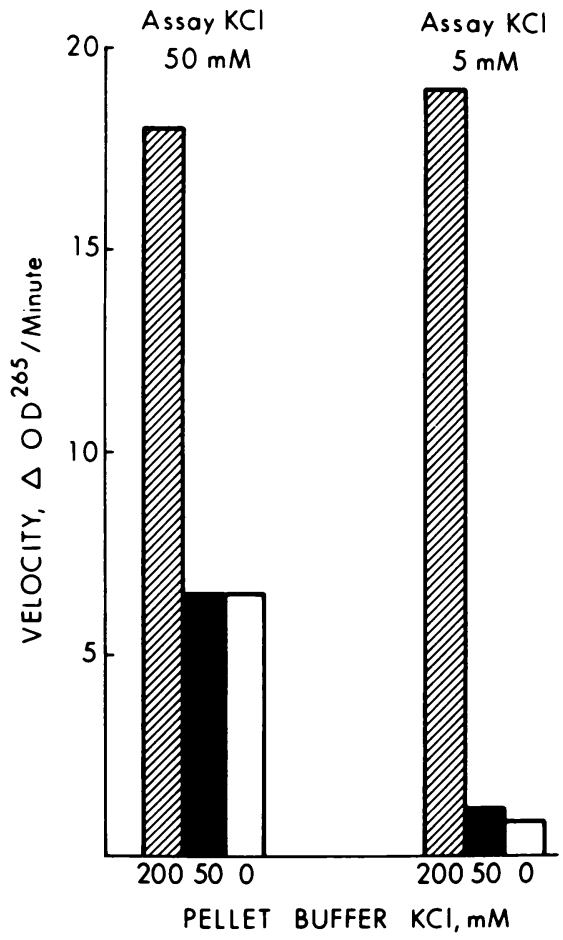

FIGURE 7 Effect of membrane binding on AMP deaminase activity. Unsealed erythrocyte ghosts $(2.0 \mathrm{mg}$ membrane protein $/ \mathrm{ml}$ ) were incubated with purified AMP deaminase (105 $\mu \mathrm{g} / \mathrm{ml}$ ), pelleted, and washed as described in the legend to Fig. 1. The washed pellets were adjusted to $570 \mu \mathrm{g} / \mathrm{ml}$ in 40 $\mathrm{mM}$ imidazole $\mathrm{HCl} \mathrm{pH} 7.5$ with 0,50 , or $200 \mathrm{mM} \mathrm{KCl}$ and incubated at $0^{\circ} \mathrm{C}$ for $15 \mathrm{~min} .50 \mu$ lof suspended membraneenzyme complexes was added to $800 \mu \mathrm{l}$ of assay mixtures containing $0.1 \mathrm{mM}$ AMP, $40 \mathrm{mM}$ imidazole $\mathrm{HCl} \mathrm{pH} \mathrm{7.5,} \mathrm{and} 0$, 3 , or $50 \mathrm{mM} \mathrm{KCl}$ such that final assay $\mathrm{KCl}$ concentrations were 3-5 mM or $50-55 \mathrm{mM}$, and assayed for AMP deaminase activity. In control experiments, when assayed under dissociating conditions ( $2 \mathrm{mM}$ AMP, $2 \mathrm{mM}$ ATP), enzymatic activity was not affected by preincubation conditions.

were washed free of AMP deaminase with $5 \mathrm{P}_{8}$ (which does not elute bound glyceraldehyde-3phosphate dehydrogenase activity). The washed ghosts were then incubated with increasing concentrations of AMP deaminase followed by assay of washed pellet fractions for bound deaminase and dehydrogenase activity. As shown in Table VI, binding of AMP deaminase is associated with progressive loss of G3PD from the membrane in a rough dose-response manner. In control experiments it was shown that purified AMP deaminase did not affect the catalytic activity of G3PD when incubated in 1:1 molar ratio, suggesting that the loss of membrane bound G3PD was not due to inactivation of G3PD by AMP deaminase, although it remains possible that when membrane bound G3PD is incubated with AMP deaminase, different effects would be found.

Sucrose gradient centrifugation. Preparations of 
TABLE VI

Effect of AMP Deaminase on the Binding of Glyceraldehyde3-Phosphate Dehydrogenase to Unsealed Erythrocyte Ghosts

\begin{tabular}{ccc}
\hline & \multicolumn{2}{c}{ Percent bound } \\
\cline { 2 - 3 } Volume of deaminase added & $\begin{array}{c}\text { Relative G.3PD } \\
\text { activity }\end{array}$ & $\begin{array}{c}\text { Relative deaminase } \\
\text { activity }\end{array}$ \\
\hline$\mu l$ & & $\%$ \\
0 & 100 & 0 \\
5 & 80 & 29 \\
10 & 85 & 54 \\
15 & 90 & 73 \\
20 & 70 & 84 \\
25 & 35 & 100 \\
Deaminase buffer, $25 \mu \mathrm{I}$ & 80 & 0 \\
\hline
\end{tabular}

Unsealed erythrocyte ghosts were incubated with increasing volumes of AMP deaminase $(0.80 \mathrm{mg} / \mathrm{ml})$ in $5 \mathrm{P}_{8}$ in a final vol of $400 \mu \mathrm{l}$. After $15 \mathrm{~min}$ at $0^{\circ} \mathrm{C}$, the ghosts were separated by centrifugation and washed twice in $10 \mathrm{mM} \mathrm{KCl}, 10 \mathrm{mM}$ imidazole $\mathrm{HCl} \mathrm{pH}$ 7.5. Pelleted membranes were then suspended in $200 \mu \mathrm{l}$ of $5 \mathrm{P}_{\mathbf{8}}$. Aliquots of the suspensions were assayed for AMP deaminase and glyceraldehyde-3-phosphate dehydrogenase activity. G3PD activity bound to freshly prepared unsealed erythrocyte ghosts and AMP deaminase activity bound to unsealed erythrocyte ghosts after incubation with $25 \mu \mathrm{l}$ of stock purified enzyme were arbitrarily defined as $100 \%$ bound. The effect of AMP deaminase stock buffer in promoting G3PD release is also shown. Purified AMP deaminase was shown to have no effect on G3PD activity when present in equimolar concentration in $5 \mathrm{P}_{8}$ (data not shown).

EDTA extracts from unsealed erythrocyte ghosts (bands 1 and 2) and $0.5 \%$ Triton X-100 extracts (band 3) previously dialyzed against $5 \mathrm{P}_{8}$ or $30 \mathrm{mM} \mathrm{KCl}$, $10 \mathrm{mM}$ imidazole ( $\mathrm{pH}$ 7.5), were incubated with equimolar concentrations of AMP deaminase for 20 min at $4^{\circ} \mathrm{C}$ before loading onto $4 \mathrm{ml}, 5-20 \%$ continuous sucrose gradients (sample vol. $0.5 \mathrm{ml}$ ). Centrifugation was performed under conditions such that AMP deaminase catalytic activity was localized in the middle third of the gradient (20-21 fractions, each $\cong 0.2 \mathrm{ml}$ ). No shift of deaminase activity in the gradient was identifiable after preincubation with EDTA-extracted material, Triton X-100-extracted material, or with glyceraldehyde-3-phosphate dehydrogenase either in phosphate or imidazole buffer, in the presence or absence of $0.5 \%$ Triton X-100. In control experiments, G3PD and partially purified band 3 were incubated together and subjected to analysis by sucrose gradient centrifugation followed by SDS gel electrophoresis of the collected fractions. The expected three-fraction shift in the position of the proteins was found, indicating that a complex between
G.3PD and band 3 had been established and that the binding site of band 3 for G3PD remained intact, in agreement with the data of others (21). The absence of an AMP deaminase shift under these conditions strongly indicates that the AMP deaminase binding site is distinct from the binding site of G3PD.

\section{DISCUSSION}

Several analogies can be drawn between the binding of AMP deaminase and G.3PD with the erythrocyte membrane. Like G3PD, AMP deaminase was found to bind specifically to the cytoplasmic surface of the erythrocyte membrane. Binding was saturable and Scatchard analysis of the binding data revealed a homogenous class of high affinity $\left(K_{\mathrm{a}} \cong 2.6 \times 10^{7} \mathrm{M}^{-1}\right)$ binding sites, which are present in limited numbers ( $n \cong 2.2 \times 10^{4} /$ cell). These figures compare favorably to the data for G.3PD (5) $\left(K_{\mathrm{a}} \cong 1 \times 10^{7} \mathrm{M}^{-1}, n \cong 2.1\right.$ $\left.\times 10^{6}\right)$ and aldolase $(6)\left(K_{\mathrm{a}} \cong 2.7 \times 10^{7} \mathrm{M}^{-1}, n \cong 1.2\right.$ $\left.\times 10^{6}\right)$. As with G3PD, there are $\cong 10$ membrane binding sites per cellular enzyme molecule. The binding data contrast sharply with the data for cytochrome $\mathrm{C}$ (5) which has been found to bind equally well to external and internal surfaces of the membrane to a rather large number $\left(n \cong 10^{7}\right)$ of low affinity binding sites $\left(K_{\mathrm{a}} \cong 10^{5} \mathrm{M}^{-1}\right)$.

As with aldolase and G.3PD, the binding of AMP deaminase was responsive to alterations of ionic strength, $\mathrm{pH}$, substrate concentration, and ATP concentration. Although $\mathrm{KCl}$ is an effective activator of A.MP deaminase, the effect of $\mathrm{KCl}$ in membrane binding was most likely nonspecific and reflects a major component of electrostatic bonding in the enzyme-membrane association, since $\mathrm{NaCl}$ and $\mathrm{CsCl}$ were equally effective in dissociating the enzymemembrane complex. Although the dissociation curve was steep at $\mathrm{pH}>7.5$, it should be noted that $\mathrm{pH}$ alone was virtually without effect on the binding equilibrium between 6.0 and 7.5. Both AMP and ATP have been shown to be activators of AMP deaminase ${ }^{2}$ and it is possible that the dissociation of the enzymemembrane complex promoted by AMP is mediated through an isosteric site of AMP on the enzyme, distinct from the AMP substrate binding site. ATP, although an allosteric activator of the enzyme, also has pronounced effects on the erythrocyte membrane (18) which may mediate ATP promoted dissociation. ATP is not an allosteric effector of G3PD but effectively dissociates the G3PD membrane complex (3).

The specific binding site of AMP deaminase has not been determined. The facts that sealed inside-out vesicles are essentially depleted of bands 1,2 , and 5 (22) and that AMP deaminase binds avidly to this preparation strongly argue against spectrin or actin as 
the binding proteins. Indeed, on sucrose gradient centrifugation no evidence for interaction of spectrin with AMP deaminase was found. The displacement of G3PD from unsealed erythrocyte ghosts by AMP deaminase suggested that band 3 might be the AMP deaminase binding protein although the displacement need not be mediated by direct competition of the two enzymes for a single binding site. Purified band 3 has been shown to form complexes both with G3PD and aldolase in purified systems $(6,21)$. However, on sucrose gradient centrifugation no interaction between band 3 and AMP deaminase or AMP deaminase and G3PD could be demonstrated. The specific AMP deaminase binding site remains unknown, although through steric proximity to the binding site of G3PD on band 3, AMP deaminase may displace G3PD by a mechanism not directly involving competition for the same site.

As with G3PD $(1,23)$, it might be argued that the association of AMP deaminase with the erythrocyte membrane represents an artifact of hypotonic lysis since dissociation of the membrane-enzyme complex is found at physiologic ionic strength and at physiological intracellular ATP concentrations $(0.5-1.5 \mathrm{mM})$. However, the membrane-enzyme dissociation curve is steep between 50 and $200 \mathrm{mM} \mathrm{KCl}$, indicating that minor fluctuations of ionic strength within the physiologic range could have major effects on enzyme binding. Furthermore, as Kant and Steck (5) have pointed out, elutability at high ionic strength does not exclude a physiologically significant phenomenon. Although ATP promotes dissociation of the complex, the effect is sensitive to $\mathrm{pH}$ fluctuations in the physiologic range, suggesting that ATP and thus cellular energy levels may also play a role in the regulation of the binding equilibrium. The localization of binding sites to the cytoplasmic surface of the membrane and the high association constant for the binding equilibrium argue for significant intracellular binding as well as for a high degree of specificity at the binding site. Binding to the membrane improved stability of purified enzyme and endogenously bound enzyme compared to purified enzyme in buffer. Because unsealed ghosts were found to enhance enzyme stability under conditions in which dissociation of membrane-enzyme complexes is expected, the significance of membrane binding in promoting enzyme stability might be questioned. The observed effect most probably reflects the dynamic interaction between membrane and enzyme, whereas experiments in which enzyme was eluted from the membrane characterized only the net balance of the equilibrium. The catalytic activity was clearly modulated by membrane binding. The favorable effect on enzyme stability provided by membrane association and the regula- tory role of membrane association on catalytic activity provide indirect evidence that membrane association may play a central role in enzyme regulation.

\section{ACKNOWLEDGMENTS}

This work was supported in part by grants CA22449 from the National Cancer Institute and HL22119 from the National Heart, Lung, and Blood Institute and by a contract with the U. S. Energy Research and Development Administration and the Franklin McLean Research Institute (operated by the University of Chicago for the U. S. Energy Research and Development Administration under contract EY-76-C-02-0069).

\section{REFERENCES}

1. Schrier, S. L. 1977. Human erythrocyte membrane enzymes. Blood. 50: 227-237.

2. Juliano, R. L. 1973. The proteins of the erythrocyte membrane. Biochim. Biophys. Acta. 300: 341-378.

3. Shin, B. C., and K. L. Carraway. 1973. Association of glyceraldehyde 3-phosphate dehydrogenase with the human erythrocyte membrane. J. Biol. Chem. 248: 1436-1444.

4. McDaniel, C. F., M. E. Kirtley, and M. J. A. Tanner. 1974. The interaction of glyceraldehyde 3-phosphate dehydrogenase with human erythrocyte membranes. J. Biol. Chem. 249: 6478-6485.

5. Kant, J. A., and T. L. Steck. 1973. Specificity in the association of glyceraldehyde 3-phosphate dehydrogenase with isolated human erythrocyte membranes. J. Biol. Chem. 248: 8457-8464.

6. Strapazon, E., and T. L. Steck. 1977. Interactions of the aldolase and the membrane of human erythrocytes. Biochemistry. 16: 2966-2971.

7. Rao, S. N., L. Hana, and A. Askari. 1968. Alkali cation activated AMP deaminase of erythrocytes: some properties of the membrane bound enzyme. Biochim. Biophys. Acta. 151: 651-654.

8. Deuel, T. F., D. R. Roth, J. Kemeny, and W. Chang. 1974. Regulation of erythrocyte adenine nucleotides: a role of AMP deaminase, 2, $3 \mathrm{DPG}$ and membrane binding. Clin. Res. 22: 387A. (Abstr.)

9. Nathans, G. R., D. Chang, and T. F. Deuel. 1978. AMP deaminase from human erythrocytes. Methods Enzymol. 51: 497-502.

10. Chaney, A. L., and E. P. Marbach. 1962. Modified reagents for determination of urea and ammonia. Clin. Chem. 8: 130-132.

11. Kalckar, H. M. 1947. Differential spectrophotometry of purine compounds by means of specific enzymes. J. Biol. Chem. 167: 445-459.

12. Ellman, G. L., K. D. Courtney, V. Andres, Jr., and R. M. Featherstone. 1961. A new and rapid colorimetric determination of acetylcholinesterase activity. Biochem. Pharmacol. 7: 88-95.

13. Steck, T. L., and J. A. Kant. 1974. Preparation of impermeable ghosts and inside out vesicles from human erythrocyte membranes. Methods Enzymol. 31: 172-180.

14. Cori, G. T., M. W. Slein, and C. F. Cori. 1948. Crystalline D-glyceraldehyde-3-phosphate dehydrogenase from rabbit muscle. J. Biol. Chem. 173: 605-618.

15. Lowry, O. H., N. J. Rosebrough, A. L. Farr, and R. J. Randall. 1951. Protein measurement with the Folin phenol reagent. J. Biol. Chem. 193: 265-268. 
16. Fairbanks, G., T. L. Steck, and D. F. H. Wallach. 1971. Electrophoretic analysis of the major polypeptides of the human erythrocyte membrane. Biochemistry. 10: 2606-2616.

17. Steck, T. L. 1972. Crosslinking the major proteins of the isolated erythrocyte membrane.J. Mol. Biol. 66: 295-305.

18. Lux, S. E., K. M. John, and T. E. Ukena. 1978. Diminished spectrin extraction from ATP depleted human erythrocytes. Evidence relating spectrin to changes in erythrocyte shape and deformability.J. Clin. Invest. 61: 815-827.

19. Yu, J., and T. L. Steck. 1975. Isolation and characterization of band 3, the predominant polypeptide of the human erythrocyte membrane. J. Biol. Chem. 250: 9170-9175.
20. Scatchard, G. 1949. The attraction of proteins for small molecules and ions. Ann. N. Y. Acad. Sci. 51: 660-672.

21. Yu, J., and T. L. Steck. 1975. Associations of band 3, the predominant polypeptide of the human erythrocyte membrane. J. Biol. Chem. 250: 9176-9184.

22. Marchesi, V. T., and E. Steers. 1968. Selective solubilization of a protein component of the red cell membrane. Science (Wash. D. C.). 159: 203-204.

23. Maretzki, D., J. Groth, A. G. Tsamaloukas, M. Gründel, S., Krüger, and S. Rapoport. 1974. The membrane association and dissociation of human glyceraldehyde-3-phosphate dehydrogenase under various conditions of hemolysis. FEBS (Fed. Eur. Biochem. Soc.) Lett. 39: 83-87. 